\title{
ECLETICA
}

www.scielo.br/ed

www.ecletica.iq.unesp.br

Volume 33, número 1, 2008

\section{Stability constants and thermodynamic parameters of cadmium complexes with sulfonamides and cephapirin}

\author{
M. S. Parihar and F. Khan \\ Department of Chemistry, Dr. H. S. Gour University, Sagar, M. P. India \\ *faridkhan58@yahoo.com
}

\begin{abstract}
Stability constant ( $\left.\log { }^{\prime}\right)$ and thermodynamic parameters of $\mathrm{Cd}^{2+}$ complexes with sulfonamide and cephapirin were determined by Polarographic technique at $\mathrm{pH}=7.30 \pm 0.01$ and $\mu=1.0 \mathrm{M}$ $\mathrm{KNO}_{3}$ at $250^{\circ} \mathrm{C}$. The sulfonamides were sulfadiazine, sulfisoxazole, sulfamethaxazole, sulfamethazine, sulfathiazole, sulfacetamide and sulfanilamide used as primary ligands and cephapirin as secondary ligand. $\mathrm{Cd}^{2+}$ formed 1:1:1, 1:2:1 and 1:1:2 complexes. The nature of electrode processes were reversible and diffusion controlled. The stability constants and thermodynamic parameters (" G, " $\mathrm{H}$ and "S) were determined. The formation of the metal complexes has been found to be spontaneous, exothermic in nature, and entropically unfavourable at higher temperature.
\end{abstract}

Keyword: polarography; stability constant; sulfonamide; cephapirin; thermodynamics.

\section{Introduction}

The investigation of metal sulfonamide compounds has received much attention due to the fact that sulfonamides were the first effective chemotherapeutic agents to be employed for the prevention and cure of bacterial infections in humans [1]. The sulphur containing ligands are well known for their anticarcinogenic, antibacterial, tuberculostatic, antifungal, insecticidal, and acaricidal activities [2]. It has been reported that the biological activity of sulphur-containing ligands gets enhanced on undergoing complexation with metal ions [2- 4]. Cephapirin is also a cephalosporin antibiotic which has a broad spectrum of activity against gram-negative bacilli and gram-positive cocci [5]. On the other hand, $\mathrm{Cd}^{2+}$ is a non-essential heavy metal that is normally present in very low concentrations in our environment [6]. However, due to industrial uses of $\mathrm{Cd}^{2+}$, some people can be exposed too much higher concentrations [7] as a result of which they suffer from many serious diseases $[8,9]$. The concentration of $\mathrm{Cd}^{2+}$ in blood and urine in human beings can be reduced by ligand therapy [10]. Sulfonamides are used in combination with other drugs as chemotherapeutic agents in bacterial infections and serious diseases in human $[11,12]$. Therefore sulfonamides alone or in combination with cephapirin could be effective against cadmium toxicity.

\section{Experimental}

All the chemicals were of analytical grade quality and their solutions were prepared in bi distilled water. Sodium salts of all the selected sulfur drugs and cephapirin (Fluka, Sigma and Aldrich) were used without any additional purification. 
$\mathrm{pH}$ measurements of the analytes were made on a Elico $\mathrm{pH}$ meter (LI - 10) using glass and calomel electrodes and fixed at 7.30 \pm 0.01 which was adjusted with dilute solutions of $\mathrm{HNO}_{3}$ or $\mathrm{NaOH}$ as required.

Electrochemical Analysis was performed using a Polarographic Analyzer (Elico, Hyderabad Model CL - 362). The Polarographic capillary was $5.0 \mathrm{~cm}$. long with diameter $0.06 \mathrm{~mm}$ with dropping mercury electrode $(\mathrm{DME})$ characteristics $\mathrm{m}^{2 / 3} \mathrm{t}^{1 / 6}=$ $2.04 \mathrm{mg}^{2 / 3} \mathrm{~s}^{-1 / 2}$. All the analytes were deaerated by pure nitrogen gas before recording the current voltage data. Potassium dihydrogen phosphate sodium hydroxide buffer was added with the analyte to stabilize its $\mathrm{pH}$.

\section{Results and discussion}

A well defined two electron [13] reversible reduction and diffusion controlled wave $\mathrm{Cd}^{2+}$ was observed in $1.0 \mathrm{M} \mathrm{KNO}_{3}$ at $\mathrm{pH}=$ 7.30 to 8.50 [14], but $\mathrm{pH}=7.30$ was selected to study the complex formation in human blood $\mathrm{pH}$. The value of $\mathrm{E}_{1 / 2}$ reversible for Cd was - $586 \mathrm{mV}$ vs SCE. The nature of current - voltage curve of $\mathrm{Cd}^{2+}$ complexes with sulfonamide and cephapirin was also reversible and diffusion controlled.

Stability constant of [Cd - sulfonamide cephapirin] complexes

In this system, the concentration of $\mathrm{Cd}^{2+}$, $\mathrm{KNO}_{3}$ and gelatin were $0.50 \mathrm{mM}, 1.0 \mathrm{M}$ and $0.001 \%$ respectively. Neither cephapirin nor sulfonamide gave their current voltage curves in 1.0 $\mathrm{M} \mathrm{KNO}_{3}$ at $\mathrm{pH}=7.30 \pm 0.01$ at $25{ }^{\circ} \mathrm{C}$. When $\left[\mathrm{Cd}^{2+}\right]$ was added with either of the drugs, complex formation was taken place and their current voltage curves were obtained. The concentration of sulfonamide in the analyte varied from 0.50 $\mathrm{mM}$ to $30.0 \mathrm{mM}$ at $0.025 \mathrm{M}$ to $0.05 \mathrm{M}$ constant concentration of cephapirin. The half wave potential $\mathrm{E}_{1 / 2}$ values become more negative with the addition of cephapirin to the binary complex [Cd - sulfonamide $]$ confirmed the $[\mathrm{Cd}$ - sulfonamide - cephapirin] complex formation. The stability constant of ternary complexes were determined by using Schaap and McMaster [15] method which confirmed the formation of $1: 1: 1$, $1: 2: 1$ and 1:1:2 metal ligand complexes. The values of stability constant of complexes were given in (Table 1). The data and plots between $F_{i j}[X$, $\mathrm{Y}]$ vs [X] for [Cd - sulfadiazine - cephapirin] complex \{where $\mathrm{X}$ and $\mathrm{Y}$ are sulfonamide and cephapirin and $i$ and $j$ are the stoichiometric numbers for primary and secondary ligands respectively\} were given in (Table 2) and (Fig. 1) respectively. The polarograms of $[\mathrm{Cd}$ - sulfadiazine - cephapirin] at [cephapirin] $=0.025 \mathrm{M}$ were given in (Fig. 2). It is clear from the polarograms that $\mathrm{E}_{1 / 2}$ values of $[\mathrm{Cd}$ - sulfadiazine cephapirin] increased with increased of the concentration of cephapirin confirmed the ternary complex formation. These ligands offered bonding to metal ion through the sulfonamido nitrogen atom and sulfonyl oxygen atom of $\mathrm{SO}_{2}$ group $[16,17]$. In case of cephapirin, $\mathrm{N}$ of the ${ }^{\prime}-$ lactam ring and $\mathrm{O}$ of the carboxylic group might take part in bond formation with $\mathrm{Cd}$ making 5 membered ring [18].

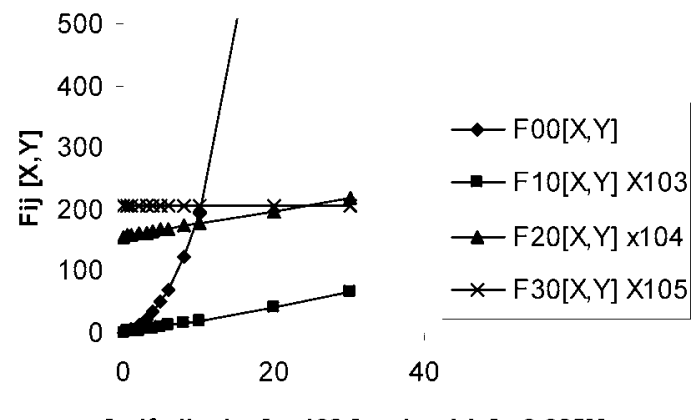

[sulfadiazine] $\times 103$ [cephapirin] $=0.025 \mathrm{M}$

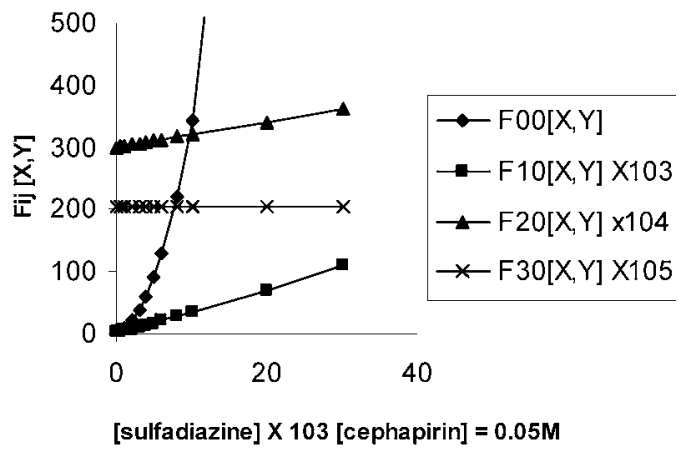

Figure 1. [Cd - sulfadiazine - cephapirin] complex. 


\begin{tabular}{|c|c|c|c|c|c|c|c|c|c|}
\hline Primary ligands & $\log \beta_{01}$ & $\log \beta_{02}$ & $\log \beta_{03}$ & $\log \beta_{10}$ & $\log \beta_{20}$ & $\log \beta_{30}$ & $\log \beta_{11}$ & $\log \beta_{12}$ & $\log \beta_{21}$ \\
\hline Sulfadiazine & - & - & - & 3.00 & 5.10 & 7.31 & 3.60 & 5.31 & 7.76 \\
\hline Sulfisoxazole & - & - & - & 3.30 & 5.23 & 7.48 & 3.70 & 5.56 & 7.83 \\
\hline Sulfamethaxyzole & - & - & - & 4.23 & 6.00 & 8.45 & 4.45 & 6.60 & 8.63 \\
\hline Sulfamethazine & - & - & - & 4.30 & 7.31 & 8.60 & 4.56 & 7.60 & 8.73 \\
\hline Sulfathiazole & - & - & - & 4.46 & 7.53 & 8.68 & 4.63 & 7.75 & 8.86 \\
\hline Sulfacetamide & - & - & - & 4.60 & 7.66 & 8.80 & 4.91 & 8.00 & 9.10 \\
\hline Sulfanilamide & - & - & - & 4.70 & 7.95 & 9.15 & 5.00 & 8.31 & 9.20 \\
\hline Cephapirin & 1.70 & 2.63 & 3.45 & - & - & - & - & - & - \\
\hline
\end{tabular}

\begin{tabular}{|c|c|c|c|c|c|c|c|c|c|c|c|c|}
\hline \multirow[b]{2}{*}{$\begin{array}{l}\text { [Sulfa.] } \\
\times 10^{3}\end{array}$} & \multicolumn{6}{|c|}{ [Cephapirin] $=0.025 \mathrm{M}$ (Fixed) } & \multicolumn{6}{|c|}{ [Cephapirin] $=0.050 \mathrm{M}$ (Fixed) } \\
\hline & $\begin{array}{l}\mathrm{E}_{\mathrm{J} / 2}{ }^{\mathrm{r}} \\
-\mathrm{V} \text { vs } \\
\mathrm{SCE}\end{array}$ & $\log \left(i_{n 2} i_{c}\right)$ & $F_{00}[X, Y]$ & $\begin{array}{l}\mathrm{F}_{10}[\mathrm{X}, \mathrm{Y}] \\
\mathrm{X} 10^{3}\end{array}$ & $\begin{array}{l}\mathrm{F}_{20}[\mathrm{X}, \mathrm{Y}] \\
\mathrm{X} 10^{4}\end{array}$ & $\begin{array}{l}F_{30}[X, Y] \\
X 10^{5}\end{array}$ & $\begin{array}{c}E_{1 / 2}{ }^{J} \\
-V \text { vs } \\
S C E\end{array}$ & $\log \left(i_{m} / i_{c}\right)$ & $\Gamma_{00}[X, Y]$ & $\begin{array}{l}F_{10}[X, Y] \\
X 10^{3}\end{array}$ & $\begin{array}{l}F_{20}[X, Y] \\
X 10^{4}\end{array}$ & $\begin{array}{l}\Gamma_{30}[\mathrm{X}, \mathrm{Y}] \\
\mathrm{X} 10^{5}\end{array}$ \\
\hline 0.00 & 0.586 & - & - & - & - & - & 0.586 & - & - & - & - & - \\
\hline 0.50 & 0.602 & 0.0072 & 3.57 & 2.01 & 157.41 & 204.17 & 0.610 & 0.0072 & 6.53 & 3.22 & 301.20 & 204.17 \\
\hline 1.00 & 0.607 & 0.0145 & 5.38 & 2.81 & 158.43 & 204.18 & 0.615 & 0.0145 & 9.66 & 4.74 & 302.22 & 204.18 \\
\hline 2.00 & 0.617 & 0.0219 & 11.44 & 4.44 & 160.47 & 204.17 & 0.624 & 0.0219 & 20.52 & 7.80 & 304.26 & 204.19 \\
\hline 3.00 & 0.624 & 0.0295 & 20.88 & 6.10 & 162.51 & 204.16 & 0.632 & 0.0295 & 37.63 & 10.90 & 306.30 & 204.18 \\
\hline 4.00 & 0.630 & 0.0371 & 33.81 & 7.81 & 164.55 & 204.18 & 0.638 & 0.0371 & 61.12 & 14.05 & 308.34 & 204.17 \\
\hline 5.00 & 0.635 & 0.0450 & 50.36 & 9.56 & 166.59 & 204.17 & 0.643 & 0.0450 & 91.10 & 17.23 & 310.38 & 204.18 \\
\hline 6.00 & 0.639 & 0.0529 & 70.66 & 11.35 & 168.63 & 204.16 & 0.647 & 0.0529 & 127.70 & 20.46 & 312.43 & 204.19 \\
\hline 8.00 & 0.646 & 0.0611 & 122.96 & 15.05 & 172.71 & 204.17 & 0.653 & 0.0611 & 221.25 & 27.04 & 316.51 & 204.16 \\
\hline 10.00 & 0.652 & 0.0611 & 191.70 & 18.91 & 176.80 & 204.18 & 0.659 & 0.0693 & 342.74 & 33.78 & 320.59 & 204.17 \\
\hline 20.00 & 0.670 & 0.0693 & 816.24 & 40.68 & 197.21 & 204.17 & 0.677 & 0.0693 & 1403.66 & 69.94 & 340.99 & 204.18 \\
\hline 30.00 & 0.681 & 0.0693 & 1998.66 & 66.54 & 217.61 & 204.16 & 0.688 & 0.0693 & 3310.17 & 110.17 & 361.41 & 204.17 \\
\hline
\end{tabular}

Thermodynamic parameters of [Cd - sulfonamide - cephapirin] complexes:

The thermodynamic parameters, free energy change (" G), enthalpy change (" H) and entropy change ("S) were calculated by following relationships [19].

$$
\begin{aligned}
& \left.{ }^{*} \mathrm{H}=\underline{2.303 \mathrm{R} \mathrm{T}} \underline{\underline{1}} \underline{\mathrm{T}}_{\underline{2}} \frac{\left(\log _{\mathrm{T}_{1}} \mathrm{~T}_{2}\right.}{\mathrm{T}_{2}}-\log _{\underline{1}}^{\prime}\right) \\
& \text { - " G = RT log } " \\
& \text { and } \\
& { }^{*} \mathrm{G}={ }^{\prime} \mathrm{H}-\mathrm{T} \cdot \mathrm{S}
\end{aligned}
$$

The thermodynamic parameters of the $[\mathrm{Cd}$ - sulfonamide - cephapirin] complexes were given in (Table 3). It is clear from the thermodynamic parameters of complexes that:

a) The stability constants $\left(\log _{1}^{\prime}\right)$ and $\left(\log _{2}{ }_{2}\right)$ decreased with increased of temperature, confirming that complexes are not stable at higher temperature [19, 20].

b) Sufficiently large negative value of " $\mathrm{G}$ showed that spontaneous formation of the complexes. Spontaneity increased with temperature, except in the $\mathrm{Cd}^{2+}$ complex [21]. 

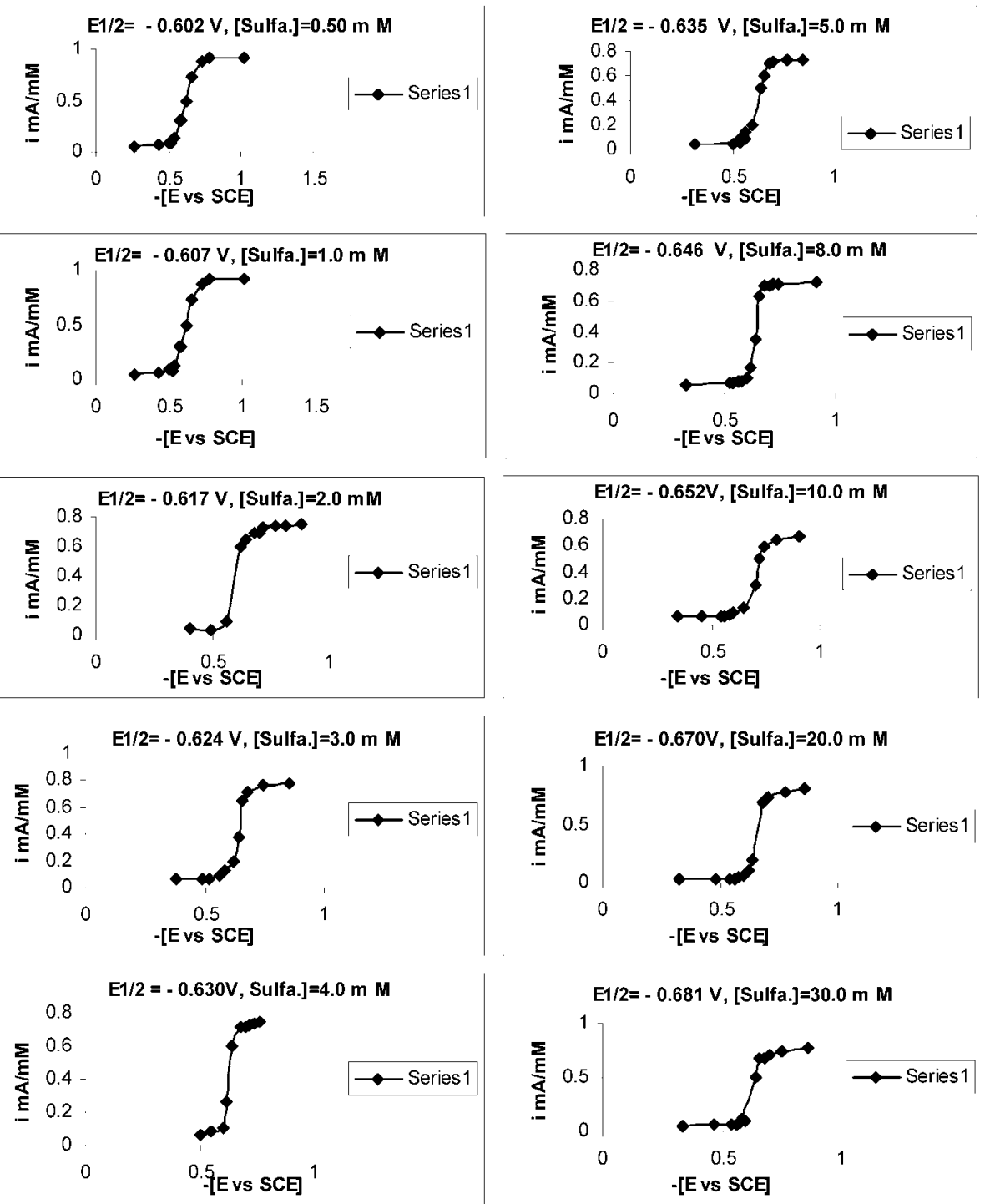

Figure 2. Polarograms of [Cd - Sulfadiazine - Cephapirin $]$ System, [Cephapirin $]=0.025 \mathrm{M}$

c) Negative values of " $\mathrm{H}$ indicated the exothermic nature of the metal-ligand interaction [21].

d) The " $\mathrm{S}$ values for the ligand complexes are negative, confirming that the complex formation is entropically unfavourable [22].

Comparison of stability of the binary and ternary complexes:

The value of mixing constant $\log \mathrm{K}_{\mathrm{m}}$, which compares the stability of binary and terna- ry complexes have been calculated by following equation [15].

$$
\log \mathrm{K}_{\mathrm{m}}=\log { }_{11}-1 / 2\left[\log { }_{02}+\log { }_{20}\right]
$$

The values of $\log \mathrm{K}_{\mathrm{m}}$ were $-0.265,-0.230$, $0.135,-0.410,-0.450,-0.235$ and -0.290 for $[\mathrm{Cd}-$ sulfadiazine - cephapirin], [Cd - sulfisoxazole cephapirin $], \quad[\mathrm{Cd}-$ sulfamethaxazole cephapirin], [Cd - sulfamethazine - cephapirin], [Cd - sulfathiazole - cephapirin], [Cd - sulfac- 
Table 3. Stability constants and the thermodynamic parameters of [Cd - sulfonamide - cephapirin] complexes at $25^{\circ} \mathrm{C}$ and $35^{\circ} \mathrm{C}$.

\begin{tabular}{|c|c|c|c|c|c|c|c|c|c|c|c|c|}
\hline \multirow{3}{*}{ Complexes } & \multicolumn{3}{|c|}{ Stability constants } & \multicolumn{3}{|c|}{ - $\Delta \mathrm{H} \mathrm{K} \mathrm{cal./mole}$} & \multicolumn{3}{|c|}{ - $\Delta \mathrm{G} \mathrm{K} \mathrm{cal} . /$ mole } & \multicolumn{3}{|c|}{ - $\Delta \mathrm{S} \mathrm{K} \mathrm{cal} . / \mathrm{mole}$} \\
\hline & $\log \beta_{11}$ & $\log \beta_{12}$ & $\log \beta_{21}$ & $\log \beta_{11}$ & $\log \beta_{12}$ & $\log \beta_{21}$ & $\log \beta_{11}$ & $\log \beta_{12}$ & $\log \beta_{21}$ & $\log \beta_{! 1}$ & $\log \beta_{12}$ & $\log \beta_{21}$ \\
\hline & $\begin{array}{c}25^{\circ} \mathrm{C} / \\
35^{\circ} \mathrm{C}\end{array}$ & $\begin{array}{c}25^{0} \mathrm{C} / \\
35^{0} \mathrm{C}\end{array}$ & $\begin{array}{c}25^{\circ} \mathrm{C} \\
35^{\circ} \mathrm{C}\end{array}$ & \multicolumn{3}{|c|}{$\begin{array}{l}\left(35^{0} \mathrm{C}-25^{\circ} \mathrm{C}\right) \\
\text { for difference of } 10^{\circ} \mathrm{C}\end{array}$} & $\begin{array}{l}25^{\circ} \mathrm{C} \\
35^{\circ} \mathrm{C}\end{array}$ & $\begin{array}{l}25^{\circ} \mathrm{Cl} \\
35^{0} \mathrm{C}\end{array}$ & $\begin{array}{l}25^{\circ} \mathrm{Cl} \\
35^{0} \mathrm{C}\end{array}$ & $\begin{array}{l}25^{\circ} \mathrm{Cl} \\
35^{\circ} \mathrm{C}\end{array}$ & $\begin{array}{l}25^{\circ} \mathrm{C} / \\
35^{\circ} \mathrm{C}\end{array}$ & $\begin{array}{l}25^{\circ} \mathrm{C} / \\
35^{0} \mathrm{C}\end{array}$ \\
\hline \multirow{2}{*}{$\begin{array}{l}\text { [Cd - sulfadiazine } \\
\text { - cephapirin] }\end{array}$} & 3.36 & 5.31 & 7.76 & \multirow[b]{2}{*}{10.5002} & \multirow[b]{2}{*}{13.0203} & \multirow[b]{2}{*}{19.3204} & 4.909 & 7.241 & 10.582 & 18.76180 & 19.39328 & 29.32330 \\
\hline & 3.35 & 5.00 & 7.30 & & & & 4.722 & 7.047 & 10.289 & 18.76182 & 19.39329 & 29.32332 \\
\hline \multirow{2}{*}{$\begin{array}{l}{[\mathrm{Cd} \text {-sulfisoxazole }} \\
\text { - cephapirin] }\end{array}$} & 3.70 & 5.56 & 7.83 & \multirow[b]{2}{*}{12.1803} & \multirow[b]{2}{*}{17.2204} & \multirow[b]{2}{*}{20.1604} & 5.046 & 7.582 & 10.678 & 23.94190 & 32.34353 & 31.82183 \\
\hline & 3.41 & 5.15 & 7.35 & & & & 4.806 & 7.259 & 10.359 & 23.94192 & 32.34355 & 31.82185 \\
\hline \multirow{2}{*}{$\begin{array}{l}\text { [Cd - sulfamethoxyzole } \\
\text { - cephapirin] }\end{array}$} & 4.45 & 6.6 & 8.63 & \multirow[b]{2}{*}{12.3903} & \multirow{2}{*}{16.7584} & \multirow[b]{2}{*}{20.1604} & 6.068 & 9.002 & 11.769 & 21.21456 & 26.03404 & 28.16097 \\
\hline & 4.16 & 6.20 & 8.15 & & & & 5.856 & 8.740 & 11.487 & 21.21458 & 26.03406 & 28.16099 \\
\hline \multirow{2}{*}{$\begin{array}{l}\text { [Cd-sulfamethazine } \\
\text { - cephapirin] }\end{array}$} & 4.56 & 7.60 & 8.73 & \multirow{2}{*}{13.0203} & \multirow[b]{2}{*}{18.9004} & \multirow{2}{*}{23.1005} & 6.218 & 10.364 & 11.905 & 22.82533 & 28.64604 & 37.56935 \\
\hline & 4.25 & 7.15 & 8.18 & & & & 5.990 & 10.077 & 11.529 & 22.82535 & 28.64607 & 37.56938 \\
\hline \multirow{2}{*}{$\begin{array}{l}\text { [Cd - sulfathiazole } \\
\text { - cephapirin] }\end{array}$} & 4.63 & 7.75 & 8.86 & \multirow[b]{2}{*}{15.9604} & \multirow[b]{2}{*}{20.8745} & \multirow[b]{2}{*}{24.3605} & 6.314 & 10.568 & 12.082 & 32.371 & 34.58394 & 41.20274 \\
\hline & 4.25 & 7.25 & 8.28 & & & & 5.990 & 10.223 & 11.670 & 32.37101 & 34.58396 & 41.20277 \\
\hline \multirow{2}{*}{$\begin{array}{l}{[\mathrm{Cd} \text { - sulfacetamide }} \\
\text { - cephapirin }]\end{array}$} & 4.91 & 8.00 & 9.10 & \multirow{3}{*}{15.1203} & \multirow[b]{2}{*}{21.5885} & \multirow{3}{*}{24.3185} & 6.696 & 10.909 & 12.409 & 28.27084 & 35.83595 & 39.96354 \\
\hline & 4.55 & 7.49 & 8.52 & & & & 6.413 & 10.551 & 12.010 & 28.27086 & 35.83597 & 39.96357 \\
\hline \multirow{2}{*}{$\begin{array}{l}\text { [Cd -sulfanilamide } \\
\text { - cephapirin }]\end{array}$} & 5.0 & 8.31 & 9.20 & & \multirow[b]{2}{*}{23.5205} & & 6.818 & 11.332 & 12.546 & 30.67785 & 40.90073 & 45.14364 \\
\hline & 4.62 & 7.75 & 8.58 & 15.9604 & & 25.9986 & 6.512 & 10.924 & 12.094 & 30.67786 & 40.90075 & 45.14367 \\
\hline
\end{tabular}

etamide - cephapirin $]$ and $[\mathrm{Cd}$ - sulfanilamide cephapirin] complexes respectively. The negative values of $\log \mathrm{K}_{\mathrm{m}}$ showed that binary complexes are more stable than their ternary complexes while in case of $[\mathrm{Cd}$ - sulfamethaxazole cephapirin] the positive value indicates that the ternary complex is more stable then their simple binary complexes.

It is clear from the values of stability constants of complexes that sulfadiazine formed the complexes of minimum stability as its complexes showed the lowest values of $E_{1 / 2}$ in comparison to the other sulfonamide complexes [23]. The stability constants of sulfisoxazole complexes are lesser than sulfamethoxazole complexes is due to the presence of two electron withdrawing $\mathrm{CH}_{3}$ groups in former than in the latter caused greater steric hindrance [24] in sulfisoxazole complexes than sulfamethoxazole complexes. Similar is the case with sulfamethazine and sulfathiazole complexes. In case of sulfactamide and sulfanilamide, the former is the $\mathrm{N}^{1}$ - acetyl-substituted derivatives of sulfanilamide formed complexes with $\mathrm{Cd}$ having lesser stability constants than sulfanilamide complexes might be the fact that it has $\mathrm{CH}_{3} \mathrm{CO}$ group [24]. The highest values of stability constants of sulfanilamide complexes amongst all other sulfonamide are due to having the largest shift of $E_{1 / 2}$ in its complexes [23]. The values of stability constants varied from 1.70 to 9.20 confirmed that either sulfonamides itself or cephapirin or in combination or their metal complexes could be effective against $\mathrm{Cd}$ toxicity [25].

\section{Conclusion}

It is clear from the study that the shift of $\mathrm{E}_{1 / 2}$ became more negative on increasing the concentration of sulfonamide and cephapirin to $\left[\mathrm{Cd}^{2+}\right]$ which confirmed the complex formation. The slope varied from $30 \pm 2 \mathrm{mV}$ confirmed that the nature of current voltage curves of metal and their complex formation is reversible. The plots between $i_{d}$ vs $h^{1 / 2}$ are straight lines passing through origin confirmed that the polarograms were diffusion controlled. $\mathrm{Cd}^{2+}$ formed 1:1:1, 1:2:1 and 1:1:2 complexes. The values of stability constants varied from 1.70 to 9.20 confirmed that either sulfonamide or cephapirin alone or in combination could be effective against $\mathrm{Cd}$ toxicity [25]. The study was also carried out at $35^{\circ} \mathrm{C}$ to determine the stability constant and thermodynamic parameters. The values of thermodynamic parameters confirmed that the complexes are not stable at higher temperature $[19,20]$. 


\section{Acknowledgements}

The authors are thankful to Head, Department of Chemistry, Dr. H. S. Gour University, Sagar, for providing the laboratory facilities and M.P. Council of Science and Technology, Bhopal for enabling the Junior Research Fellowship to M. S. Parihar.

\section{Received 17 November 2007 Accepted 10 February 2008}

\section{References}

[1] S. Bellu, E. Hure, M. Trape, M. Rizzotto, Quim. Nova 26 (2003) 188.

[2] M. Jain, R. V. Singh, Bioinorg. Chem. Appl. 13743 (2006) 1. [3] K. K. Chaturvedi, R. V. Singh, J. P. Tandon, J. Pract. Chem. 327(1) (1985) 144.

[4] K. Singh, Indian J. Chem. 30A (1991) 283

[5] H. G. Robson, M. I. Bowmer, Antimicrob. Ag. Chemother. 6 (1974) 274.

[6] B. Cicik, K. Engin, Turk. J. Vet. Anim. Sci. 29 (2005) 113 [7] G. S. Shukla, R. L. Singhal, Can. J. Physiol. Pharmacol. 62 (1984) 1015.

[8] Principles and Methods of Toxicology, A. Wallace
Hayes. Taylor and Francis Publishing Inc.; Philadelphia, $4^{\text {th }}$ ed., 2001

[9] I. H. Bukhari, M. N. Hassan, A. Haleem, M. Bhatti, Res. J. Agric. \& Biol. Sci. 2 (2005) 190.

[10] F. Khan, J. Chin. Chem. Soc. 52 (2005) 569.

[11] J. G. Hardman, L. E. Limbird, Goodman \& Gilmans, The Pharmacological Basis of Therapeutics, The McGraw-Hill Companies, New York, $10^{\text {th }}$ ed., 2001, p.1173.

[12] C. R. Craig, R. E. Stitzel, Modern pharmacology with clinical Application, Lippincott Williams and Wilkins. $6^{\text {th }}$ ed., 2003.

[13] T. Devries, J. L. Kroon, J. Am. Chem. Soc. 75 (1953) 2484.

[14] L. Meites, Polarographic Technique, Interscience Pub., New York, $2^{\text {nd }}$ ed., 1965 , p. 62.

[15] W. B. Schaap, D. L. McMaster, J. Am. Chem. Soc. 83 (1961) 4699.

[16] S. Pritchett, P. Gantzel, P. J. Walsh, Organometallics 18 (1999) 823.

[17] G. N. Mukherjee, P. Dhar, J. Indian Chem. Soc. 64 (1987) 142.

[18] F. Khan, J. Chin. Chem. Soc. 54 (2007) 673.

[19] F. Khan, L. Tantuvay, J. Pharm. Biomed. Anal. 27 (2002) 933.

[20] A. A. Al-sarawy, Chem. Pap. 58(2) (2004) 109.

[21] T. Atalay, E. G. Akgemci, Turk. J. Chem. 24 (2000) 89.

[22] E. G. Akgemci, T. Atalay, Turk. J. Chem. 22 (1998) 123.

[23] R. C. Kapoor, B. S. Aggarwal, Principles of Polarography, Wiley Easter Ltd., Delhi (1991).

[24] M. Calvin, A. E. Martell, Chemistry of Metal Chelate Compounds, Prentice Hall Inc., New York, $2^{\text {nd }}$ ed., 1953, p.134. [25] M. D. Walker, D. R. Williams, J. Chem. Soc. (Dalton) (1974) 1186. 